\title{
Cortisol responses to physical and pharmacological stimuli in heifers
}

\author{
Isabelle VEISSIER, P. LE NEINDRE
}

Laboratoire de l'Elevage Bovin,

I.N.R.A., Theix, 63122 Ceyrat, France.

Summary. The aim of this study was to assess bovine plasma cortisol response to blood sampling, to 5-min isolation in a novel arena and to dexamethasone blockade and ACTH stimulation. Twelve 10-month old heifers of the Friesian and Salers breeds were used. Blood collection, carried out via a jugular cannula or caudal venipuncture, had no significant effect on cortisol level. This level increased by about $20 \mathrm{ng} / \mathrm{ml} 10 \mathrm{~min}$ after the heifers were isolated in the novel arena, and it returned to the initial value within $70 \mathrm{~min}$. Cortisol response at $10 \mathrm{~min}$ was a good indicator of overall response and was also related to the animal remaining motionless in the arena. The cortisol level declined $14 \mathrm{hrs}$ after dexamethasone injection. Intramuscular or intravenous administration of ACTH resulted in a large increase (maximum: $44 \mathrm{ng} / \mathrm{ml}$ above the initial level), and high levels were maintained from 30 to $180 \mathrm{~min}$ following injection. The cortisol level at $30 \mathrm{~min}$ seemed to be a reliable indicator of mean response to ACTH.

\section{Introduction.}

This study was done in view of further behavioural experiments including blood cortisol concentration as a measurement of response to environmental stressors. We used two standardized methods. Firstly, the cortisol levels were studied before and after short isolation in a novel arena, as in the " open-field " test for rodents (see review of Archer, 1973). Secondly, the activity of the adrenal cortex was measured after stimulation by exogenous ACTH. These methods are generally used to measure respectively the short-term effects of a given situation (Lachaux et al., 1983 ; Dantzer et al., 1983) and the long-term consequences of rearing conditions (Shayanfar et al., 1975; Smith, Hansel and Coppock, 1975 ; Friend et al., 1977 ; Dantzer et al., 1983).

Some methodological points needed to be clarified before applying these methods extensively to cattle. Our objectives were:

- to specify the effects of the sampling procedures since restraint and blood sampling themselves could enhance cortisol concentrations (Stephens and Tonner, 1975), 
- to determine the cortisol curves after either an isolation test or ACTH stimulation. To our knowledge, this curve had never been studied in detail after isolation in a novel arena, and great variations were found in ACTH stimulation tests for the time needed to reach the peak : from 30 min (Dunlap et al., 1981) to $3 \mathrm{hrs}$ (Wagner, Strohbehn and Harris, 1972), and the time needed to return to basal levels : from 3 hrs (Venkataseshu and Estergreen, 1970) to more than $8 \mathrm{hrs}$ (Dunlap et al., 1981).

The present work proposes simplified procedures based on the determination of optimal sampling intervals and of methods of blood collection as well as on comparisons of the routes of ACTH injection. We also attempted to relate the various adrenal responses to one another and to behaviour during isolation.

\section{Material and methods.}

We used a total of twelve 10-month old heifers during the winter. Four Salers and four Friesians were used as experimental animals. Four other Friesians used as controls were only submitted to cannula sampling. All were housed in the same room and tethered individually by a chain around the neck. They were fed hay and concentrates at 0700 and 1700 hrs. Jugular cannulae were inserted without anesthesia the day prior to the experiment. The animals were sampled where tethered and with minimal handling. The blood sampling schedules are shown in figure 1.

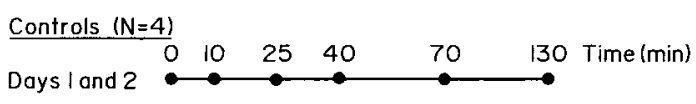

Experimental heifers $(\mathrm{N}=8)$

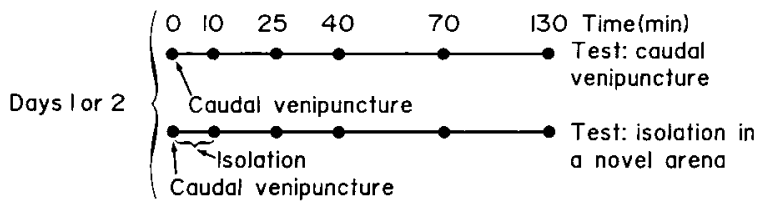

Day 2 17.00 hrs: cannula sampling then injection of dexamethasone

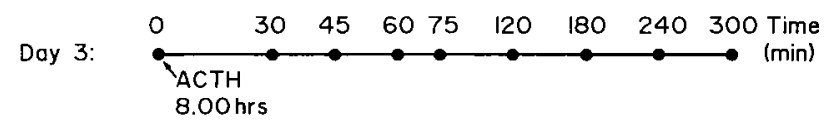

FIG. 1. - Sampling schedules.

: cannula sampling

On days 1 and 2, both the control and experimental heifers were assigned to the same cannula sampling schedule. The series of blood samplings were initiated at $0930 \mathrm{hrs}$ for all experimental heifers not given isolation tests and at $1000 \mathrm{hrs}$ 
for all the controls. For the experimental heifers to be isolated, the series were initiated at 50-min intervals; the first animal was first sampled at $0930 \mathrm{hrs}$ and the last one at $1200 \mathrm{hrs}$. All the experimental heifers received a caudal venipuncture soon after the first cannula sample was taken (time 0 ). The isolation tests were carried out on half the experimental animals on day 1 and on the other half on day 2. Immediately after caudal venipuncture, the heifer to be isolated was taken in a lorry to a small $(3 \times 4 \mathrm{~m})$ novel arena $300 \mathrm{~m}$ away from the shed. It was left there for $5 \mathrm{~min}$ and then returned to the shed. The whole procedure took less than $10 \mathrm{~min}$. The arena was dimly lighted and the animal had no visual or auditive contact with other beings. The floor was uncovered and marked off into four equal rectangles to determine ambulation. Behaviour was recorded on a videotape. We determined the number of rectangles entered, the time the heifer remained motionless and the frequency of sniffing.

The procedure used for pharmacological testing was that of Dantzer and co-workers (Dantzer et al., 1983; Mormede et al., 1984). On the evening of day 2 at $1700 \mathrm{hrs}$, all the experimental animals were sampled, then injected intramuscularly with $20 \mu \mathrm{g} / \mathrm{kg}$ of dexamethasone acetate in benzyl alcohol (Dectancyl, Roussel). This product was expected to suppress endogenous cortisol secretion so that the heifer would have low levels of cortisol when ACTH was injected (Toutain et al., 1982). On the morning of day 3 at $0800 \mathrm{hrs}$, the blood was sampled and $0.5 \mathrm{mg} /$ heifer of $\mathrm{ACTH}$ (Synacthene Immediat, Ciba-Geigy) was administered. This dose was administered by intramuscular route in two Salers and two Friesians and by intravenous route in the others $\left({ }^{1}\right)$. It corresponded to about $0.17 \mathrm{IU} / \mathrm{kg}$.

Blood was collected in heparinized tubes and immediately centrifuged. Plasma aliquots were stored at $-18{ }^{\circ} \mathrm{C}$ for 7 months. All assays were performed at the same time. Plasma cortisol was determined by radiocompetition with a labelled cortisol $\left({ }^{125} \mathrm{I}\right)$ for a limited number of antibody binding sites (CORTCTK Kits, CIS, France), according to the method described by Cabello and Levieux (1980). Intra-assay variation was $5 \%$ for concentrations ranging between 100 and $200 \mathrm{ng} / \mathrm{ml}$ and $8 \%$ for $20 \mathrm{ng} / \mathrm{ml}$; assay sensitivity was $0.05 \mathrm{ng} / \mathrm{ml}$. Only cortexolone and 17-hydroxyprogesterone cross-react with the antibody, but in physiological concentration they do not affect the determination of cortisol levels.

Since variances were heterogeneous, the comparisons were tested with non-parametrical statistics (paired measurements: Wilcoxon tests when $\mathbf{N}$ exceeded 6, or else sign tests; unpaired measurements: Mann-Whitney tests). The concordance coefficient of Kendall was calculated over the whole sampling period to confirm that the 8 experimental heifers had homogeneous cortisol responses in trend $(W=0.83, N=22$ cannula samples per animal ; $P<0.005)$. The effects of cannula sampling, caudal venipuncture, isolation in the arena, dexamethasone blockade and ACTH stimulation were evaluated by comparing the cortisol levels determined in jugular blood at each interval with those

(') Dantzer et al. only used the intravenous route. 
determined at time 0. Further calculations were based on these differences, i.e. responses measured at each interval, or on their mean, i.e. mean response. The values given in the text refer only to the initial level and to deviations from it, that is, to responses, except when " absolute " level is mentioned. Cortisol responses were analysed by component analyses at any interval after (a) isolation and (b) ACTH injections (Lebart and Fenelon, 1975). Thereafter, the correlations between the initial variables and the first axis of these analyses (parametrical statistics) were calculated. Optimal sampling intervals were determined from those that showed a high correlation. The correlations between cortisol responses and behaviour in the novel arena were also analysed; Spearmann correlations were used since the behavioural data were not normally distributed. Details on the number of animals and on the variables included in the analyses are given below. The null hypothesis was rejected whenever $P>0.05$. The variation from the mean was expressed as the standard deviation.

\section{Results and Discussion.}

The values obtained on the experimental heifers never differed significantly from one breed to another, so the results were grouped together.

\section{Initial level.}

The initial cortisol level determined from the cannula sample at time 0 on both day 1 and day 2 averaged $4.5 \pm 1.2 \mathrm{ng} / \mathrm{ml}(\mathrm{N}=12$; average time : $1000 \mathrm{hrs})$. Diurnal variations in bovine cortisol level have been reported by Wagner and Oxenreider (1972) and MacAdam and Eberhart (1972), though daily rhythmicity remains questionable (Hudson et al., 1975). The value we obtained is consistent with those previously reported at about the same time of day (MacAdam and Eberhart, 1972: $4 \mathrm{ng} / \mathrm{ml}$ between 0830 and $1030 \mathrm{hrs}$; Hudson et al., 1975 : $7.3 \mathrm{ng} / \mathrm{ml}$ between 0800 and $1200 \mathrm{hrs}$; Dunlap et al., $1981: 6.4$ and $6.1 \mathrm{ng} / \mathrm{ml}$ at $0800 \mathrm{hrs})$. The initial level in the present work did not vary significantly from day $1(5.1 \pm 2.5 \mathrm{ng} / \mathrm{ml})$ to day $2(3.9 \pm 2.0 \mathrm{ng} / \mathrm{ml})(\mathrm{N}=12 ;$ Wilcoxon test : $P>0.05)$. A Wilcoxon test did not reveal any significant discrepancy between the two methods of blood collection (jugular blood: $4.7 \pm 2.4 \mathrm{ng} / \mathrm{ml}$, caudal blood : $4.7 \pm 1.8 \mathrm{ng} / \mathrm{ml} ; \mathrm{N}=16 ; \mathrm{P}>0.05)$.

\section{Response to blood collection.}

The effects of cannula sampling were assessed from the data collected on the controls. A slight response was seen at $t=10 \mathrm{~min}$ (fig. 2); at that time, cortisol level was higher than its initial level in three heifers out of four on day 1 , and in one heifer on day 2 (cortisol response at $10 \mathrm{~min}: 9.0 \pm 9.9 \mathrm{ng} / \mathrm{ml}$ on day 1 and $2.1 \pm 6.8 \mathrm{ng} / \mathrm{ml}$ on day 2). However, the difference between the level at $10 \mathrm{~min}$ and the initial level was not statistically significant $(N=8$; Wilcoxon test: $P>0.05)$ nor was the difference between day 1 and day 2 response $(N=4$; sign test: $P>0.05$ ). 
The effects of caudal venipuncture were assessed from data collected on days 1 and 2 from the experimental heifers that were not isolated in the arena. There was a slight enhancement at $t=10 \mathrm{~min}$ (fig. 2) but, again, the difference from the initial level was not statistically significant $(N=8$; Wilcoxon test: $P>0.05)$.

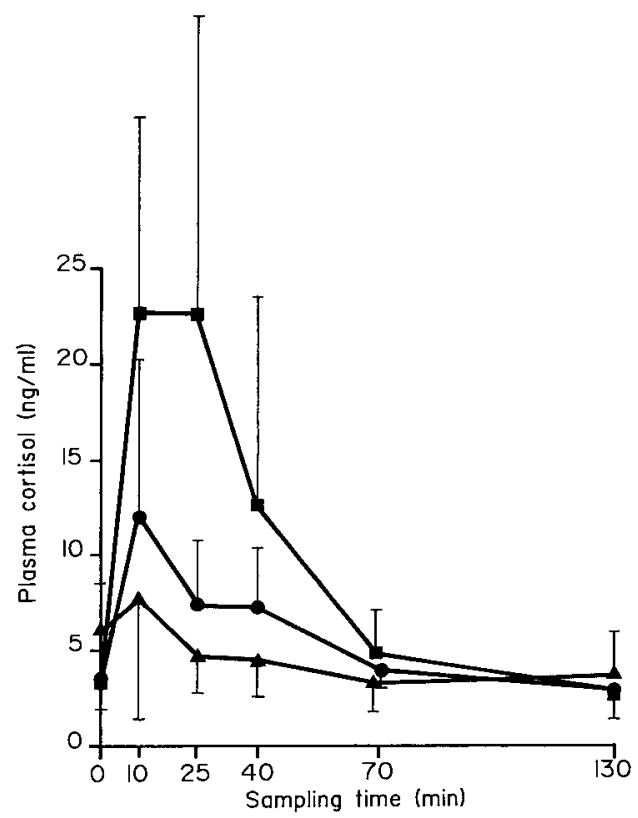

FIG. 2. - Cortisol responses to blood collection and to the novel arena.

- cannular sampling only $(N=4$ control heifers $) ; \Delta$ : caudal venipuncture $(N=8$ experimental heifers); $\mathbf{\square}$ : exposure to the novel arena ( $N=8$ experimental heifers).

The failure to detect any response to cannula sampling alone or to additional caudal venipuncture appears contrary to previous findings by Stephens and Tonner (1975). This may be due to the fact that their animals were restrained for blood collection since Echternkamp (1984) showed that glucocorticoid level was enhanced after cannula sampling only if the animals were not accustomed to handling. We suggest that two caudal venipunctures can be performed in behavioural tests of reactivity, providing that handling is minimal. However, the further effects of repeated caudal venipuncture are still not known.

Response to isolation in the novel arena.

The cortisol concentration largely increased during isolation in the novel arena (fig. 2). The initial level seemed to be restored by $t=70 \mathrm{~min}$ (fig. 2). Wilcoxon tests revealed that the cortisol level was significantly higher than 
initially only at $t=10,25$ and $40 \min (N=8 ; P<0.005$ at these three intervals). Moreover, these increases were significantly higher than those obtained at the same intervals on the experimental heifers that were subjected only to caudal venipuncture $(\mathrm{N} 1=\mathrm{N} 2=8$; Mann-Whitney tests : $\mathrm{P}<0.005$ at 10,25 and $40 \mathrm{~min}$ ).

Mean cortisol response was not correlated with initial cortisol level ( $r s=-0.21$ ). The first axis of the component analysis performed on the five measurements of the cortisol response expressed $77 \%$ of the inter-individual variability. The correlations with this axis were 0.77 at $10 \mathrm{~min}, 0.96$ at $25 \mathrm{~min}$, 0.94 at $40 \mathrm{~min}, 0.87$ at $70 \mathrm{~min}$ and 0.83 at $130 \mathrm{~min}(\mathrm{~N}=8 ; \mathrm{P}<0.05)$. The only behavioural measurement significantly correlated with an hormonal level was the time the heifers remained motionless in the arena. This behavioural trait was significantly correlated with cortisol response only at $10 \min (\mathrm{N}=8 ; \mathrm{rs}=0.79$; $P<0.05)$ and $70 \min (N=8 ; r s=0.69 ; P<0.05)$. The longer an animal remained motionless, the higher was the response. According to the sampling schedule used in this experiment, $10 \mathrm{~min}$ and $70 \mathrm{~min}$ appeared to be the best intervals for assessing the reaction to isolation in a novel arena. Since no significant increase was found between the initial cortisol level and that at $t=70 \mathrm{~min}$, we suggest using a $10-\mathrm{min}$ interval, if only one post-test sample can be collected.

\section{Pharmacological tests.}

The cortisol level declined significantly from day 2 at $1700 \mathrm{hrs}$, when dexamethasone was injected (absolute level : $3.56 \pm 0.94 \mathrm{ng} / \mathrm{ml}$ ), to day 3 at $0800 \mathrm{hrs}$ (absolute level : $1.34 \pm 0.27 \mathrm{ng} / \mathrm{ml})(\mathrm{N}=8$; Wilcoxon test : $\mathrm{P}<0.005)$. This result agrees with that of Toutain et al. (1982) who reported that bovine cortisol concentrations decreased over the first $24 \mathrm{hrs}$ after intramuscular injection of $0.1 \mathrm{ml} / \mathrm{kg}$ of dexamethasone 21 isonicotinate in propylene glycol. Moreover, the cortisol level determined on day 3 at $0800 \mathrm{hrs}$ was significantly lower than the mean initial level determined on both day 1 and day $2(N=8$; Wilcoxon test : $P<0.01$ ).

The cortisol level rose considerably after ACTH administration (fig. 3). The initial level did not seem to be reached at the end of the sampling schedule, that is, $300 \mathrm{~min}$ after the injection. Wilcoxon tests revealed that between $\mathrm{t}=30$ and $180 \mathrm{~min}$, the cortisol level was significantly higher than that determined at 0800 hrs ( $N=8$; Wilcoxon tests : $P<0.01$ at any interval between 30 and $130 \mathrm{~min})$.

Two peaks were distinguished on the cortisol curve $45 \mathrm{~min}$ and $75 \mathrm{~min}$ after ACTH administration (fig. 3). The polyphasic shape of the curve could be due to $\mathrm{ACTH}$ acting on cortisol synthesis at different stages with differential latencies for each stage (for review on ACTH mechanisms of action, see Dazord, 1983).

Mean response was not significantly correlated with initial level ( $r s=0.12$ ). The first axis of the component analysis performed on the eight measurements of the cortisol response expressed $73 \%$ of the inter-individual variability. The correlations with this axis were significant at 30,75,120,180, 240 and $300 \mathrm{~min}$ (respectively, $r=0.85,0.86,0.98,0.97,0.88$ and $0.87 ; N=8 ; P<0.01$ ). The 


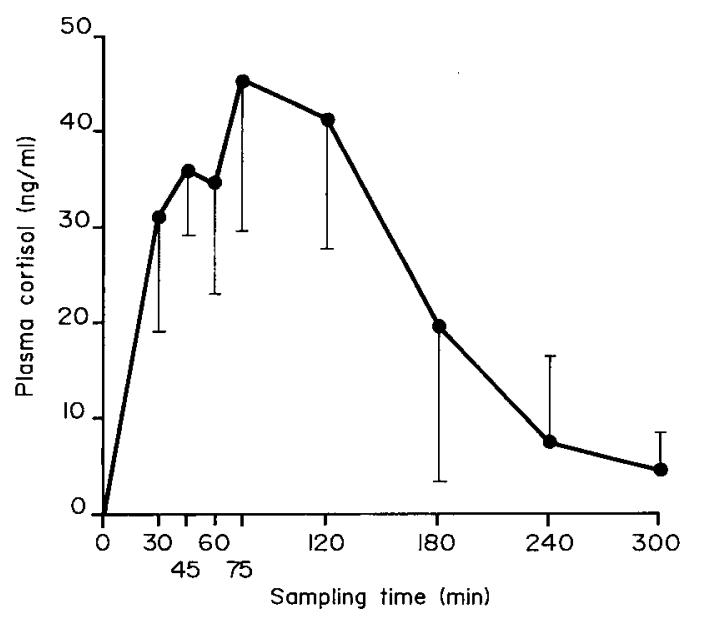

FIG. 3. - Cortisol response to ACTH stimulation ( $\mathrm{N}=8$ experimental heifers).

responses measured at 45 or 60 min were not significantly correlated to the first axis. Based on the literature, it would seem that the cortisol level determined within 30 min after ACTH administration is always situated on the first ascending portion of the curve, but that after 30 min the shape of the curve depends on the rearing conditions and physiological state of the animal (see data reported by Shayanfar et al., 1975 ; Smith et al., 1975 ; Kejela et al., 1978 ; Friend et al., 1977). Thus, although in the present experiment cortisol levels after 75 min were more correlated with the first axis of the component analysis than that at $t=30 \mathrm{~min}$, this last interval would usually be chosen if only one post-test sample is to be collected.

The maximal increase $(44.0 \pm 15.6 \mathrm{ng} / \mathrm{ml}$ at $\mathrm{t}=75 \mathrm{~min})$ was greater than that obtained by Dantzer et al. (1983) using exactly the same procedure on 3 -month old calves (about $23 \mathrm{ng} / \mathrm{ml}$ ). It appeared similar to those found in cows (Venkataseshu and Estergreen, 1970; Friend et al., 1977 ; Friend, Gwazdauskas and Polan, 1979; Gwazdauskas et al., 1980; Dunlap et al., 1981) (from 50 to $90 \mathrm{ng} / \mathrm{ml}$ ). Apart from Gwazdauskas et al. (1980), who injected ACTH in quantities similar to ours, the above authors used larger amounts (200 IU per animal, which is about $0.35 \mathrm{lU} / \mathrm{kg}$ ), and a positive relation between the dose of ACTH and the magnitude of the response was found by Paape et al. (1977). Furthermore, their procedures did not include dexamethasone blockade which is known to lessen subsequent response to ACTH (Toutain et al., 1982). Consequently, the response we observed appeared to be more pronounced than usually described. This might result from differences in animal age or in the type of exogenous ACTH used.

In our study, intramuscular injections of ACTH induced higher, but more variable, response than intravenous injections (mean response : intramuscular route : $32.5 \pm 12.1 \mathrm{ng} / \mathrm{ml}, \mathrm{N}=4$; intravenous route : $29.7 \pm 3.3 \mathrm{ng} / \mathrm{ml}, \mathrm{N}=4$ ). 
However, the differences were not statistically significant at any interval or for mean response (Mann-Whitney tests: $P>0.05$ ).

Relationship between exposure to the novel arena and pharmacological tests.

Correlations were calculated between cortisol response to dexarnethasone, mean response to ACTH or to exposure to the arena and behaviour in the arena. The increases of cortisol level in response to ACTH or to the arena appeared to be linked ( $r s=0.88 ; P<0.01)$ and opposite to the decrease observed after dexamethasone injection (respectively, $r$ s $=-0.59$ and $-0.64 ; P<0.05$ only in the second case). There was no significant correlation between behaviour in the arena and response to either dexamethasone or ACTH.

\section{Conclusions.}

Jugular and caudal bloods had very similar cortisol concentrations. Serial cannula sampling of blood and caudal venipuncture did not significantly affect cortisol concentration. However, the limited amount of material might account for the lack of effect. Nonetheless, it is sure that the significant enhancement during 5 -min isolation in the novel arena did not result only from blood collection. Therefore, we suggest two caudal venipunctures to measure response to isolation, one immediately before the test and a second one $10 \mathrm{~min}$ later since response measured at this interval is representative of the whole sampling period and of behaviour in the arena.

We also propose using two caudal samples, taken at a 30-min interval, to assess the response to exogenous ACTH stimulation after dexamethasone blockade. However, response to ACTH can be affected by age (Moberg et al., 1980), physiological state (Dunlap et al., 1981) or sex (Mormede et al., 1984). Though this procedure is likely to provide accurate results for 10-month old heifers, it is not clear that it can be extended to other animals.

The more sensitive the pituitary axis was to dexamethasone blockade, the less sensitive it was to either exogenous or endogenous ACTH.

Reçu en avril 1987.

Accepté en décembre 1987.

Acknowledgements. - We are grateful to D. Broom, P. Poindron, R. Dantzer and P. Mormede for critically reviewing the manuscript. We thank G. Cabello and C. Wrutniak for help with the assays.

Résumé. Réponses corticotropes à des stimuli physiques ou pharmacologiques chez les génisses.

Le niveau plasmatique des glucocorticoïdes est classiquement utilisé pour évaluer la réactivité d'un animal à son environnement : l'axe corticotrope est stimulé sous l'effet d'un stress mais, à la suite de stress répétés, il devient beaucoup moins sensible à l'action stimulante de l'ACTH ou au rétrocontrôle négatif des corticoïdes. Ce travail a pour but de 
préciser, chez les Bovins, l'évolution de la cortisolémie en réponse soit à une prise de sang, soit à une épreuve de $5 \mathrm{~min}$ d'isolement dans une enceinte inconnue, soit à une injection de dexaméthasone puis d'ACTH. L'étude porte sur 12 génisses Frisonnes ou Salers âgées de dix mois.

La prise de sang, par cathéter intrajugulaire ou par ponction de la veine caudale, reste sans effet sur la cortisolémie. Le niveau du cortisol plasmatique est multiplié par dix entre 10 et 25 min après le début de l'épreuve d'isolement, il reste supérieur à son niveau initial pendant au moins $40 \mathrm{~min}$. La réponse mesurée à $t=10 \mathrm{~min}$ donne la meilleure estimation de la réponse moyenne. De plus, à cet intervalle, la réponse corticotrope est significativement corrélée à la durée d'immobilité dans l'enceinte $(r s=0,79)$.

Quinze heures après l'injection d'une forme retard de dexaméthasone, la cortisolémie chute d'environ $1 / 3$. Elle est multipliée par 13 dans les deux heures suivant l'injection intraveineuse ou intramusculaire d'une forme rapide d'ACTH. La réponse à I'ACTH enregistrée à $t=30 \mathrm{~min}$ semble l'indicateur le plus fiable de la réponse moyenne.

Des procédures simplifiées d'évaluation des réponses corticotropes sont proposées.

\section{References}

ARCHER J., 1973. Tests for emotionality in rats and mice : a review. Anim. Behav., 21, 205-235.

CABELLO G., LEVIEUX D., 1980. Neonatal changes in the concentrations of thyrotropin, triiodothyronine, thyroxine and cortisol in the plasma of the pre-term and full-term lambs. $J$. dev. Physiol., 2, 59-69.

DANTZER R., MORMEDE P., 1979. Le stress en élevage intensif. Masson, Paris, $117 \mathrm{pp}$.

DANTZER R., MORMEDE P., BLUTHE R. M., SOISSONS J., 1983. The effect of different housing conditions on behavioural and adrenocortical reactions in veal calves. Reprod. Nutr. Dév., 23, $501-508$.

DAZORD A., 1983. Mécanisme d'action de l'ACTH. Ann. Endocrinol., 44, 15-28.

DUNLAP S. E., KISER T. E., COX N. M., THOMPSON F. N., RAMPACEK G. B., BENYSHEK L. L., KRAELING R. R., 1981. Cortisol and luteinizing hormone after adrenocorticotropic hormone administration to postpartum beef cows. J. anim. Sci., 52, 587-593.

ECHTERNKAMP S. E., 1984. Relationship between LH and cortisol in acutely stressed beef cows. Theriogenology, 22, 305-311.

FRIEND T. H., POLAN C. E., GWAZDAUSKAS F. C., HEALD C. W., 1977. Adrenal glucocorticoid response to exogenous adrenocorticotropin mediated by density and social disruption in lactating cows. J. Dairy Sci., 60, 1958-1963.

FRIEND T. H., GWAZDAUSKAS F. C., POLAN C. E., 1979. Change in adrenal response from free stall competition. J. Dairy Sci., 62, 768-771.

GWAZDAUSKAS F. C., PAAPE M. J., PEERY D. A., McGILLIARD M. L., 1980. Plasma glucocorticoid and circulating blood leuckocyte response in cattle after sequential intramuscular injections of ACTH. Am. J. Res. Vet., 41, 1052-1056.

HUDSON S., MULLORD M., WHITTLESTONE W. G., PAYNE E., 1975. Diurnal variations in blood cortisol in the dairy cow. J. Dairy Sci., 58, 30-33.

KEJELA G., HEAD H. H., WILCOX C. J., THATCHER W. W., 1978. Adrenal responsiveness in preand postpartum dairy cows. J. Dairy Sci, 61, 1736-1741.

LACHAUX M., BOUISSOU M. F., BERGES J. C., ORGEUR P., 1983. Etude du comportement en open-field de béliers lle-de-France soumis à différentes conditions d'élevage. Bio/. Behav., 3, 257-269.

LEBART L., FENELON J. P., 1975. Statistique et informatique appliqués. Editions Dunod, Paris, pp. 222-256.

MacADAM W. R., EBERHART R. J., 1972. Diurnal variations in plasma corticosteroid concentrations in dairy cattle. J. Dairy Sci., 55, 1792-1795.

MOBERG G. P., ANDERSON C. O., UNDERWOOD T. R., 1980. Ontogeny of the adrenal and behavioral responses of lambs to emotional stress. J. anim. Sci., 51, 138-142. 
MORMEDE P., DANTZER R., BLUTHE R. M., CARITEZ J. C., 1984. Differences in adaptative abilities of three breeds of Chinese pigs : behavioural and neuroendocrine studies. Génét. Sél. Evol., 16, 85-102.

PAAPE M. J., DESJARDINS C., GULDRY A. J., MILLER R. H., SMITH V. R., 1977. Response of plasma corticosteroid and circulating leukocytes in cattle following intravenous injection of different doses of adrenocorticotropin. Am. J. vet. Res., 38, 1345-1348.

SHAYANFAR F., HEAD H. H., WILCOX C. J., THATCHER W. W., 1975. Adrenal responsiveness in lactating Holstein cows. J. Dairy Sci, 58, 870-878.

SMITH R. D., HANSEL W., COPPOCK C. E., 1975. Plasma adrenocorticoid response to corticotropin in dairy cattle fed high silage diets. J. Dairy Sci., 58, 1708-1712.

SNEDECOR G. W., COCHRAN W. G., 1957. Méthodes statistiques. The lowa State University Press, Ames, $593 \mathrm{pp}$.

STEPHENS D. B., TONER J. N., 1975. Husbandry influences on some physiological parameters of emotional responses in calves. Appl. anim. Ethol., 1, 233-243.

TOUTAIN P. L., BRANDON R. A., ALVINERIE M., GARCIA-VILLAR R., RUCKEBUSCH Y., 1982. Dexamethasone in cattle : pharmacokinetics and action on the adrenal gland. J. vet. pharmacol. Therap., 5, 33-43.

VENKATASESHU G. K., ESTERGREEN Y. L., 1970. Cortisol and corticosterone in bovine plasma and the effect of adrenocorticotropin. J. Dairy Sci., 53, 480-483.

WAGNER W. C., OXENREIDER S. L., 1972. Adrenal function in the cow. Diurnal changes and the effects of lactation and neurohypophyseal hormones. J. Dairy Sci., 34, 630-635.

WAGNER W. C., STROHBEHN R. E., HARRIS P. A., 1972. ACTH, corticoids and luteal function in heifers. J. anim. Sci., 35, 789-793. 